\title{
Theatre and Cultural Education as Panacea for Nigeria's Fractured Peace: Ofo na Ogu as Paradigm
}

\author{
Alex Chinwuba Asigbo \& Kelechi Stellamaris Ogbonna \\ http://dx.doi./org/10.4314/ujah.v18i1.1
}

\begin{abstract}
Ofo na Ogu are Igbo cultural concepts that symbolize righteousness and uprightness. They are used in Igbo Sociocultural and religious discourse to stake claims of innocence hence the aim of this work is to examine the appropriation of these cultural motifs in Igbo literary drama and theatre. How can a creative use of these motifs serve as a unifying force for a nation at the throes of disintegration? Can the invocation of these symbolic objects help in the attempt to ensure high moral standards, especially in public offices? These and some others will be the issues which this paper will be attempting to address.
\end{abstract}

\section{Introduction}

Art exists within the ambiance of culture which in turn has variously been described as the folk ways or a people's way of life. Its concern with humanity and nature implies a relationship that awakens mankind to the realities of a given environment or social situation. It is the performative art that moves culture from one mind to another and from a familiar terrain, to an unfamiliar one. Thus, the culture of a people embodies their total way of life, language, lores and mores, including their beliefs, values, food and patterns of relating with one another. These distinguish a people from another and identify them as peculiar in their own way. People of the same culture place value on the same things and 
frown at aberrations of the same kind. The Igbo are located in the Southeast of Nigeria for which Ekwunife explains that:

The Igbo occupy the Southern part of Nigeria between the latitudes of 5 and 7 degrees northward and longitudes 6 and 7 degrees eastward. The land mass stretches up to 15,600 square miles. The Igbo are bordered by the Igala and Idoma people to the north, the Ijaw and Ogoni to the south, the Yako and Ibibio people to the east and the Bini and Warri people to the west. (2)

For the Igbo, their lores and mores guide the people's religious, cultural and socio-political activities. This is evident in their language, dressing and life style which speak for them wherever they go. But with the advent of Western civilization, inter marriages and political /trade pacts, the Igbo are losing their culture and are creating subcultures that can be refered to as "Vampire culture that are aided, even if unwittingly, by the very people who ought to protect them" (Duruaku, 4).

It is observable that the fusion of cultures creates its own problems and leaves a people empty- empty because they are now neither here nor there. Yet, culture is dynamic. But when a people abandon their culture to accept another's, they lose their identity and become mediocre, because they are neither masters in the new culture nor are they identified in the legends and myths of the new culture. That is why Asigbo reminds us of the age old saying that "any nation that turns its back on its arts and culture is doomed to decadence" (19) hence, Duruaku is right to observe that:

When a people begin to forget their origins; their values that are embedded in stories, myths and the mores of their tribe that distinguish them from others; their past and how 
they have developed over the millennia, they begin to lose their identity and the individuality that makes them unique members of the human family. (4)

Thus, cultural dynamism modifies and improves an individual and his society. It enhances a people and ensures peace and stability. However, a wholesome adoption of foreign culture fractures the peace of an individual and that of his society. That is why Ogbonna and Onaivi argue that "the origin of these conflicts can be traced to religious and cultural neglect as a result of wholesome adoption of Western values/culture which its consequent result is the present chaos" (52). While culture is who we are, theatre is the totality of who we are in action. From the festivals enshrined in our myths, legends and folklore to the stories told during the moonlight nights, our dances and Oro (hide and seek game), had been a festival theatre of some sort from ancient times. Although ours has been an oral tradition which has been a disadvantage, yet these performative cultures performed the function of cultural education.

In the South East of Nigeria, the Igbo were known for their uprightness and functional way of justice. For instance, it was generally taken for granted that each man knew what was right and wrong and stayed away from actions perceived as dishonest and self-serving as well as all acts that were considered abominable. This does not mean that there were no evil men in the land. No! Every society has its share of wickedness. But the Igbo had a guiding principle, a natural religion, a culture of justice upon which both the rich and the poor relied and were subject to. It was the Ofo na Ogu. This was because the phrase 'ejikwam ogu o'! (I am innocent) can only be uttered by the just. Peradventure one whose hand is not clean says that, and he or she is subjected to swear by the $O f o$, such a person will face the wrath of God and 
bear its consequences. Often times, the consequences are not pleasant. More so, Mbiti informs that:

Wherever the African is, there is his religion: he carries it to the fields where he is sowing seeds or harvesting a new crop; he takes it with him to the bear party or to attend a funeral ceremony; if he is educated, he takes religion with him to the examination room at school or in the university; if he is a politician he takes it to the house of parliament...(2)

Thus, $O f o$ is the symbol of justice in Igbo land. It is the philosophy of fairness exercised to maintain what is morally right and to eschew evil in the community.It is germane to note that before now, the Igbo revered the Ofo and will always speak the truth, swear the truth and abstain from evil. But times have changed and with the marriage of cultures and the dominance of Christian religion over the Traditional African Religion, the Igbo now swear with the Bible and believing that the Christian God is ever merciful, slow to anger, he or she indulges in all manner of lies in order to excel.

From the foregoing, it would be right to say that our people have abandoned their norms and values to adopt new ones. This acculturation has not been to our advantage since the new culture is introducing some negative orientation that impedes on peaceful coexistence and human development. Especially now that religion has occupied the front burner in national issues; honesty, justice and morality have been thrown to the back seat. Why not? Because those in authority, the culturati, including the elders and chiefs who are aware of the efficacy of the Ofo na $O g u$ (symbol of justice and equity) hide under their new religious affiliation to commit horrendous crimes. Hence, we continue to swim in the ocean of 
lies, dishonesty, violence and man's inhumanity to man. The recipients of the entire injustice and violence are the poor masses whose peace is taken away, who pay for the food those in authority eat. Whose sweat and sufferings pay for the difference in subsidy, who toil day and night to receive a pittance as wage in order to buy a litre of kerosene for \#300 (three hundred naira).

\section{Drama (Theatre) and Cultural Education}

Drama and Theatre, even though having noticeable dissimilarities, will be used interchangeably in this discourse. This is because, while drama is primarily written literature, theatre is drama interpreted through the medium of stage. This means in a manner of speaking, that one gives birth to the other hence our resolve to use them as one and the same thing. Theatre as a medium to promote positive norms and values is not just accessible but a better way of learning ones culture. It is a "medium that can orient and disorient, used for good or bad, and is capable of molding characters as well as achieving set targets." (Utoh-Ezeajugh \& Ogbonna, 13). Because theatre creates conducive atmosphere for learning and interactions, it becomes an accessible pipeline to orient the people towards understanding and aligning to their culture.

It was Owusu who opined that "the representation of action in any given society, employing aspects of culture in terms of the activity itself...make drama or theatre a most effective vehicle for the promotion of culture, especially in the educational realm" (14). Theatre edifies both the performer and the audience. Through theatrical performances and cultural/traditional practice certain cultures can be popularized and preserved because according to Sarpong there are accounts that: "In African traditional religion, there are certain abiding principles which promote human values 
and good living. They defy time. They are the values upon which the Creator designed things in such a way that the Africans could survive" (16).

But the clamour for Western education and foreign values has devalued African cultural values. This is because "the very concept of the school in colonial times was (sic) found on the promotion of imperialist interests" (Nwamuo, 1). The academia then was responsible for the imposition of Western culture. This has robbed Africa of its positive moral values and societal norms. It has replaced folktales, moonlight stories and games of African extraction with cartoons of American and Chinese myths leaving the African child empty and vulnerable. The youth, including the adult Igbo may not be able to speak the Igbo language fluently, or re-tell a myth from his culture but will be quick to recount an English tale and the myth and legends of British experience. Theatre parades the Nigerian culture in action because the dramatic performance is spiced with religious and cultural beliefs hence Ogbonna and Onaivi recorded that:

Nigerians/ (sic)African had identity established in norms and customs that guarded their economic, social, political and religious lives. The monotheist belief in one God who is refered to as Chineke (Igbo), Olorun Olodumare (Yoruba), Allah (Hausa), Abasi (Calabar), Aondo (Tiv), Owoicho (Idoma), Inkosi Yaphezulu (Zulu in South Africa), Onyame(Asante of Ghana), and the Kenyans call him Nandi. Although each tribe or ethnic group have their own culture but the beauty of the cultural difference is that each clan/tribe/ethnic respected the culture and traditions of each other and interpreted their conflicts and social problems within the context of their beliefs and values (52) 
From the fore going, it is imperative to urgently embark on cultural education in homes, community gatherings, public places and offices. For example, the myth behind the existence of the fourmarket days in Igbo land is rarely known by youths and adults of contemporary age. It is through cultural contents in theatrical performances that such information can be passed down to the audience. Toni Duruaku in his play, Matter of Identity, conceived abstract characters like Eke, Orie, Afo, and Nkwo. By so doing he preserves not only the market days but also the myth behind their existence. It is not enough to introduce African clothes into our work places once a week, perhaps on Fridays, but to be at home with our culture at all times so that Nigerians can speak with one voice in a common language for a common cause.

Through theatre, one's culture is not only preserved, it equally grows with the society, transforms and cultures the individual. Cultural and traditional elements contained and parodied on stage reflect the essential values of a people and the African thoughts upon life. With these in performance, models are set to repair and reform cracked walls that torment the individual and his society. This goes to imply that "... as actors of the day, they are custodians of the community's culture and hold the key to its history, when the plays they perform are re-enacted two hundred, four hundred or two thousand years hence" (Owusu,18). Theatre is the wheel on which culture rides.

Basically, since theatre is a communication medium, culture has been used and influenced by it as well. The plot of any performance relies on the human psychology which controls the characters, the conflict, mood and actions in the play. UtohEzeajugh and Ogbonna affirm that:

The selected scenes of everyday life in families, villages, communities, social structures, micro and macro societies 
in African drama reveals that there are lessons to be learnt from cultural tenets embedded in such dramatic pieces. (13)

It is obvious that theatre chronicles aspects of a people's culture through its setting, character formation, language, conflicts and how resolution is achieved. A dramatic performance before an audience is a repertoire or commentary on a people's cultural life. The audiences are therefore tutored, informed and invariably through them cultural materials; totems, myths, norms and values are preserved. The dances, songs, rites, rituals, totems, images and parables are aspects of culture and everyday occurrences that performances reveal. The performative art with its aesthetic allure is a potent tool that registers on the mind of the audience vivid images, it teaches while entertaining. In performance, these aspects of culture find expressive platform to illustrate themselves and their utilitarian functions.

The Igbo religion can be traced down to a natural discovery of man as a means to relate with the Supreme Being. It is this religious tradition that transforms into the people's culture. Hence culture being the way of life of a people, sprouted from the land and was passed down from generation to another. Through these cultural media such as the kindred, family, festivals, age grade, theatre and dance, positive values were transmitted to children and indeed, adults. Hence cultural education was in progress through the people's oral tradition. Theatre on the other hand was part of the people's culture and a medium often used to entertain, inform, satirize and burlesque with norms and values. It is a vehicle through which legends and myths are preserved. 


\section{Ofo na Ogu in Igbo Religious Thought}

The Igbo traditional religion has a monotheist belief in the Supreme Being-the Almighty God. Also, the Igbo religion is pantheist, of which Okafor summarizes as follows:

1. Belief in Chukwu, the supreme being-God

2. Belief in other minor deities (nature gods)

3. Belief in other spirits (good and evil ones)

4. Belief in reincarnation

5. Belief in immortality

6. Belief in reward and punishment for good or evil done on earth. (29)

Based on the above listed beliefs, the Igbo are guided by their religion knowing that steps in the right direction attract positive rewards and wards off danger. This belief has transformed into an acceptable cultural concept among the Igbo; the Ofo na ogu. Ofo is a powerful symbol used in Igbo religion. The Igbo believe in the efficacy of the $O f o$. Njaka points out that:

$O f o$ is the central symbol of the Igbo religion. In addition to being a staff of authority, it is an emblem symbolizing the links between Chukwu and man, the dead and the living, the living and the unborn. The Ofo also symbolizes justice, righteousness, and truth (35)

The $O f o$ is sacred and stands out among other articles of faith in the Igbo religion. Ofo affirms the maxim that 'he who must ask for justice must come with equity' Ofo is both symbolic and material while $O g u$ is an abstract concept which literarily means innocence. $O g u$ is a communal and religious concept which one invokes in order to establish innocence. $O f o$ and $O g u$ go hand in hand hence $O f o n a O g u$; illustrates that he who holds or swears by $O f o$ must 
hold $O g u$ (Innocence) too. There are several categories of $O f o$ : $O f o$ dibia (held by a Dibia), Ofo Isi-Opara (held by the first male of the family or the oldest male of the family), Oke-Ofo (a clan/kindred/community $O f o$, usually held by the oldest male who uses it to perform clan/ kindred/communal functions) and others depending on the practice in a particular community. However, Okafor enlightens us on the status of Ofo saying that:

All Ofo are not of equal importance and status. The $O f o$ are classed under two main categories namely, the ancestral $O f o$ and the individual $O f o$ acquired at maturity by males. The ancestral $O f o$ is handed down from generation to generation...like the individual $O f o$, each social or political unit has its own $O f o$ which is separate from and greater than any individual $O f_{o}$ in that unit...the village $O f o$ is greater than the family $O f o$ and that of the village group is greater than the village Ofo. Usually, the Okpara is the holder of the family Ofo. Because of this he performs a leading role in all political and religious functions... A devout $O f o$ holder says his daily prayer fervently with his Ofo placed on the ground. (30)

Since $O f o$ is symbolic, it can be anything that symbolizes justice. But Okafor further informs that "The Ofo is possessed exclusively by the adult males. Their female counterparts used the "umune" in the same way as an $O f o$ is used by the adult males" (30), only that in a case of a woman dibia, she possesses the same Ofo-dibia that the male dibias have. But $O f o$ has a tree that bears the Ofo seed. $O f o$ is synonymous with Omenana (tradition); it is the basis of natural religion which as explained by Umeh is "the Ofo of the Sacred Ekwo (mystical pyramid) which the first Nri was said to be given by God was used for the purpose of cleansing abominations" 
(134). Simply put, Ofoism is to the Igbo what Judaism is to the Hebrew. Basically, Ofo na ogu is one of the principles which Akwuba as contained in Ekwunife, considers relevant as he opines that:

The Nuclues family of the traditional Igbo where the primary socialization of children and cultural education are given; the kindred or the extended family system for selfhelp and security of the members; The power and attraction of symbols like the Ofo symbol of authority; and the concept of brotherhood which stresses the value of communal life and discourages individualism, selfishness and so on. (qtd in Ekwunife, 20)

$O f o$ is to the natural Igbo religion the beginning and the end of socio-political and moral ethics albeit it is based on the poetic oral tradition. Achebe in Umeh is quoted as saying that "the world in which we live has its double and counterpart in the realm of the spirits" (23), hence the Ofo checkmates the physical activities of the individual and his community in order to correspond same with the expectations of the spiritual realm. Thus the saying "Ofo ka idide ji awa ana - the sacred staff of truth, office, authority, justice and fair play is what the earthworm idide uses in burrowing the ground. Umeh also affirms that the concept of $O f o$ regulates ethics and norms (48). It helps the just in times of danger because "Oji Ofo ada-ato n' ije...the just and the truthful person is never lost in a journey" (49). So, Ofo is greater than riches, wealth, political power and position, that is why the Igbo maxim "Ofo ka nsi...Ofo is greater than poison or evil ' $O g w u$ ' (49) affirm the potent power of Ofo. Ofo which goes with $O g u$ is both implied and actual because the concept of it is as efficacious as the physical/symbolic representation of it. 
Ofoism, which contemporarily, is a mutual cultural concept amongst the Igbo, is actually a universal truth. Because the concept is based on the golden rule that the righteous does not suffer, a person with clean hands cannot suffer what he is not guilty of. But things are changing and the righteous go to jail while the dubious occupy exalted seats. Why? The reason is not farfetched. It is because the people have abandoned the truth, their religion, culture, norms, and values. They no longer swear by the Ofo neither do they appeal for justice through the culturally established models. Because they know of its potent value and the consequences against the person who lies, kills, robs and lives unjustly. Thus, the $O f o n a O g u$ in its abstract, symbolic and material concept is fast fading out from communal life due to the adoption of foreign religion and Western values

These abstract concepts of Ofo na Ogu embedded in folktales, myths and legends helps to propagate positive culture that inculcates peace, leadership and moral values to both children and adults. Because folktales serve other purposes beyond entertainment which Obiechina admits that "folktale makes us think, feel, perceive, and therefore empathise; it enables us to integrate our consciousness, educate our minds, purify our souls, and refine our sensibilities" (26). Also the concept of libation is symbolic and can be linked to Ofoism, for it is only when ones hands are clean that he or she can pour libations. Therefore, when such concepts are incorporated in any form of dance, drama or festival theatre, it promotes norms and values that are needed for peaceful co-existence. Theatre humanizes, it creates an atmosphere of peace and dialogue. Hence, through performance which is a veritable tool for cultural awareness, models of peace and stability are showcased to the audience who in turn implements it in their daily activity. The academia or elite class is well positioned to 
champion this cultural reawakening since by their place in society, they are seen as opinion molders.

\section{The Academia}

It was some of the elites who promoted Western values and abandoned the African culture and religion. This they did not only through Western education but also by changing their names to foreign ones, and adopting lifestyles that are strange to African values. The not-so-literate looked upon the elites as models and had no option than to emulate the elites. Consequent upon this, what we have today are people who are confused and bedeviled with all manner of crimes. The youth live a lifestyle that seems right and good since there are no alternatives in sight. Having been exposed to television, radio, internet and all forms of global media, the very youth lack the knowledge of his native culture and what the norms and values are.

Although African culture had its limitations because it lacked documentation, the oral tradition was its primary mode of preservation and transfer of norms and values. Obiechina records that "past traditions were largely preserved in human memory and transmitted orally" (8) hence children learnt from their parents, elders, guilds, age grades, events/festivals and groits. It was a mouth-to-ear mode of transmission. Therefore, the academia has a role to play in facilitating a change of attitude in our people using the instrumentality of theatre and cultural education in Nigeria. This the academia can do through writing, translations, adaptations and medium switch in order to revive dying African cultures. It is the academic who will have to write down this oral culture into Igbo language and from Igbo language to English language. This is because if the culture continues to exist in its oral nature, it will become extinct as the people who know it die. It was Sule who 
understood the need for proper documentation of cultural facts when he wrote that:

We stand the risk of losing some of our most positive cultural treasures in the form of ...values and knowledge...in various areas of human endeavour if proper attention is not readily accorded this task of documentation of oral evidence (20)

Another thing the academia can do towards cultural reorientation will be to initiate a medium switch and move the folktales from the plane of story-telling to the stage of performance. Medium switch can transform a poem to a theatrical performance and a Stage performance to a Film. The stage helps to preserve and promote an idea hence Duruaku opines here that "...if folktale is performed, it means that the story is preserved by the narrator and the audience who in turn preserve it through transmission from 'father to son'..." (10) This facilitates cultural education amongst the audience. Again, aesthetics and audio-visual nature of performance highlights those aspects of culture that needs to be preserved in the world of play. Also it behooves the academia to enlighten their families, students, communities and wider public on the inherent benefits of theatre and performance, because:

For a society like Nigeria where interest in reading literature has bowed to the new theatre of television soap, graphics, games and the internet browsing, the way to go is to adapt the stories into short plays so that children and indeed adults can perform them in the local language (Duruaku,13).

Hence, writers, actors, directors, choreographers and producers are urged to be conscious of cultural and traditional elements in their 
writings and productions. These elements may not only serve to enhance spectacle but through its projections/inclusion will carry messages. When such scripts or improvisations are orchestrated on stage, children, youths and adults will not only become aware of their existence, meanings and messages, but will begin to appreciate the unique nature of African culture. It is the academia who will effectively pilot theatre and cultural education amongst the people. This is because once they take that step and create the need for people to fall back to positive African values, the Igbo, Nigerians and Africans will begin to see their culture as unique and valuable.

\section{Conclusion}

That Nigeria and indeed, the Igbo nation are passing through very trying times is not in doubt. What however has remained contentious is the possible way out of the woods for Nigeria. Social commentators and the religious of various calling have proffered solutions to the seeming chaos that has become the lot of Nigeria to a confounding level. As usual, most of these suggestions have tended to privilege foreign anti-dotes against local remedies. As said elsewhere by Asigbo, any invention or solution that lacks a cultural basis is doomed to failure (2013).

This is why in this piece we have proposed a return to our cultural and religious roots. This return is predicated on the concept of Ofo na Ogu - the Igbo practice and symbol of right and wrong and regulator of social relations which we advocate should be appropriated in our writings and productions. It is obvious that most foreign religions through which symbols our political office holders take their oaths of office have failed in the task of enforcing morality on us. (Asigbo, 2013). The way out would therefore be for us to embrace the Ofo na $O g u$ as it has proven 
efficacious in the enforcement of morality, fairness and equity in social relations.

\author{
Alex Chinwuba Asigbo \\ Department of Theatre Arts \\ Nnamdi Azikiwe University, Awka \\ ac.asigbo@unizik.edu.ng; \\ alexasigbo@yahoo.com \\ \& \\ Kelechi Stellamaris Ogbonna \\ Department of Theatre Arts \\ Alvan Ikoku Federal College of \\ Education, Owerri \\ kellyogbonna@yahoo.com; \\ kellytamarisk@gmail.com
}

\title{
Works Cited
}

Asigbo, Alex. Footpaths to the Future: The Writer as Visionary in a dysfunctional Society. Being a Keynote Address Presented at the 2013 Annual Conference of the School of Arts, Alvan Ikoku Federal College of Education, Owerri, 2013.

Asigbo, Alex. Fighting From the Trenches: Nigerian Playwrights and The Task of Nation Building. $23^{\text {rd }}$ Inaugural Lecture of Nnamdi Azikiwe University, Awka, Valid Publishing Company, 2013.

Duruaku, Toni. ABC. Medium Switch for the Preservation and Promulgation of an Igbo Folk Heritage. School of Arts Lecture Series 1 Alvan Ikoku Federal College of Education, Owerri. July $26^{\text {th }}$, 2011. Print. 
Ekwunife, A. N. O. A Consecration in Igbo Traditional Religion. Nsukka: Jet Publishers, 1990.

Print.

-“"African Traditional Religion and Mordern development in Nigeria" African Traditional Religion, philosophy and Sustainable Development. Ed. Elizabeth Onyedinma Ezenweke. Jos: Association of African Traditional Religion and Philosophy Scholars, 2014. 1-48

Njaka, E.N. Igbo Political Culture. Evanston: Northwestern University Press, 1974. Print.

Nwamuo, Chris. The Teaching Performance: The Context of the African Post-Colony. In Sankofa: Journal of the Humanities. Vol.3 No.2.(1-13). Ghana: Department of Theatre Arts, University of Ghana, 2005. Print.

Mbiti, John S. African Religions and Philosophy. Ibadan: Heinemann, 1974. Print.

Obiechina, Emmanuel. Nchetaka: The Story, Memory and Continuity of Igbo Culture. Ahiajoku

Lecture. Owerri: Ministry of Information and Social Development. 1994.

Okafor, F. U. Igbo Philosophy of Law. Enugu: Fourth Dimension Publishers, 1992. Print.

Ogbonna, Kelechi S \& Onaivi, Lucy A. "Cultural and Traditional Measures as Panacea for Peace and Security: A Study of Selected Nigerian Play" In Majac: Makurdi Journal of Arts and Culture. Vol.11 No.2. (49-64). Makurdi: department of Theatre Arts, Benue State University, 2013. Print.

Onyemuchara, Casmir. "Sustaining the Cultural Heritage of Ndi Igbo: The Dance Experience". Being a Paper Presented at the School of Arts Conference at Alvan Ikoku Federal College of Education, Owerri, 2010. Print. 
Owusu, Martin O. "Drama and Cultural Education: A Theatre Perspective" In Sankofa: Journal of the Humanities. Vol. 3 No. 2. (14-23). Ghana: Department of Theatre Arts, University of Ghana, 2005. Print.

Sule, Belo. Documentation and Cultural Development. Lagos: National Council for Arts and Culture, 1991.

Ukeje, B. O. School and Society in Nigeria. Enugu: Fourth Dimension Publishers, 1982. Print.

Umeh, John A. After God is Dibia. Vol.1. London: Kamak House, 1997. Print.

Utoh-Ezeajugh, Tracie C. \& Ogbonna, Kelechi S. "Cultural Imperatives for Peace and Security in African Drama: Ogonna Agu's Symbol of a Goddess and Sunnie Ododo's Hard Choice as Paradigms" In The Creative Artist: A Journal of Theatre and Media Studies. (12-31). Awka: Theatre Arts Department, Nnamdi Azikiwe University, 2013. Print. 